\title{
PENDIDIKAN KARAKTER BERDASARKAN PENGAMALAN NILAI - NILAI MORAL PANCASILA SEBAGAI JATI DIRI BANGSA INDONESIA
}

\author{
Oleh : \\ Drs. Luh Suryatni, MSi \\ Dosen Tetap Fakultas Hukum Universitas Dirgantara Marsekal Suryadarma Jakarta. \\ Email : (luhsuryatni@gmail.com)
}

\begin{abstract}
:
Character is a trait which a combination of internalized moral values from outside ourselves and potentials existing in us. These potentials are gifts from God as our identity then become our nature. Later, on our journey in life, we will choose which nature will became the essential value in life. For example, honesty, it cannot be taken for granted. Honesty need to be strived for in each of our actions. You can be known about having a character when you able to perform honestly. Whereas identity crisis of a nation should not be allowed to drag on. There should be an efforts to deal with it, in order for the nation to find its true identity while rekindling its spirit and soul, rooted by the nation character itself there will be no doubt when facing various challenges and problems. Therefore, the development of national character is aimed to construct personal and family sustainability which become the foundation of the national sustainability. The fragility of national sustainability can be caused by the weakness in personal and family sustainability. So far, this weakness is due to personal sustainability just focusing in the competency and knowledge rather than studying the character development also. Personal character is a key which is not touched of all fronts. The main problem is the absence of handbook in how to develop a character. Thus, effective effort is required to develop the character of a nation through education and training for everyone, at every occasion in form of implementation of the existing and ongoing education also training revitalization.
\end{abstract}

Keyword : Character Education, The Moral Values Of Pancasila, and Identity Of The Nation Of Indonesia.

\section{Pendahuluan}

Kesadaran kebangsaan yang mengkristal yang lahir dari rasa senasib dan sepenanggungan, akibat penjajahan telah berhasil membentuk wawasan kebangsaan Indonesia seperti yang tertuang dalam sumpah pemuda pada tahun 1928, yaitu tekad bertanah air satu, berbangsa satu, dan menjungjung bahasa persatuan, yaitu
Indonesia. Tekad bersatu ini kemudian dinyatakan secara politik sebagai bangsa yang merdeka dan berdaulat baik secara de facto tanggal 17 Agustus 1945 dan secara de jure tanggal 18 Agustus 1945.

Sekarang bangsa ini mulai menyadari kembali, bahwa karakter bangsa sebagai pemersatu seluruh rakyat ini, kurang dirawat dan kurang diperhatikan, yang 
secara langsung maupun tidak langsung telah menurunkan wibawa bangsa ini, di samping tuntutan jaman agar menjadi bangsa yang tangguh dalam menghadapi persaingan global di dunia internasional, maka dirasakan perlunya kebijakan nasional pembangunan kembali ke Karakter Bangsa. sebagaimana tercantum dalam Undang-Undang No. 17 tahun 2007 tentang Rencana Pembangunan Jangka Panjang Nasional 2005-2025. Kiranya tidak etis, jika kita semua membiarkan rakyat yang menjadi korban dari berbagai tekanan permasalahan, dan mereka akan semakin menderita dari generasi ke generasi berikutnya, karena kehilangan arah dan pedoman, kehilangan tokoh panutan yang bisa dijadikan andalan, 'berjalan sendirian' dengan kebingungan bagaimana mengatasi masalah besar tanpa ada yang membela kepentingan mereka. Kepentingan yang paling mendasar bagi rakyat jelata cukup sederhana, yakni hanyalah cukup makan dan ada jaminan keamanan dan keadilan. Perlu kita sadari, bahwa masalah paling berat yang diakibatkan oleh tantangan yang tidak terjawab secara tuntas, adalah krisis identitas bangsa akibat dari rapuhnya Karakter Bangsa, keadaan ini akan membawa bangsa ini berada dalam 'keadaan darurat' yang ditandai oleh:

1. Sebagian warga merasa kurang bangga menjadi warga negara Indonesia, kalau sedang di luar negeri dan bertemu orang asing, tidak mau mengaku sebagai warga negara Indonesia atau bahkan ingin berpindah kewarganegaraannya menjadi warga negara asing.

2. Terdapat oknum aparatur pemerintah yang lebih mementingkan kepentingan pribadinya di atas kepentingan yang lain termasuk di atas kepentingan bangsa dan negara, akibat individualistik yang dominan, nasionalisme sempit, primordialisme, fanatisme kelompoknya.

3. Berkurangnya partisipasi dan peran aktif seluruh rakyat dalam kepentingan bangsa dan negara, dengan lebih memilih untuk bersikap masa bodoh dan tidak mau tahu dengan segala upaya pemerintah.

Krisis identitas bangsa tidak boleh dibiarkan berlarut-larut, harus ada upaya untuk mengatasinya agar bangsa ini menemukan jati dirinya kembali, sekaligus mengobarkan kembali semangat dan jiwa kebangsaan yang berakar pada jati diri bangsa, agar mereka tidak ragu, untuk menjawab berbagai tantangan permasalahan bangsa.

Pendidikan karakter individu di dalam pelajaran secara berkelanjutan (never ending process) inilah yang harus diperkenalkan dan ditularkan kepada para anak didik sehhingga orientasi pembangunan karakter selain diberi muatan ilmu pengetahuan juga penting untuk ditanamkan dan disosialisasikan nilai-nilai sosial-budaya, wawasan kebangsaan dan nilai-nilai (karakter) Pancasila. Sehingga, anak didik akan tumbuh dan berkembang sebagai seorang anak remaja dan kemudian menjadi anak dewasa yang berkarakter, berbudaya Indonesia, berwawasan kebangsaan dan menampilkan karakter yang memancarkan nilai-nilai pancasila. $\mathrm{C}$ a ra menyalurkan pembangunan karakter yang paling efektif memang melalui jalur pendidikan, baik pendidikan informal, formal maupun nonformal dalam upaya penanaman dan pembangunan karakter dengan sadar dan sengaja serta dilakukan secara berkelanjutan. 
Pendidikan informal berarti pendidikan yang dilakukan di rumah dalam jalur keluarga. Karena itu, melalui bimbingan ajaran dan keteladanan hal ini pendidikan karakter dapat dilakukan secara terus menerus sejak bayi berada dalam kandungan sampai dengan kita meninggal dunia. Karena anak-anak memiliki kecenderungan mengucapkan apa yang ia dengar, dan melakukan apa yang ia lihat. Apa yang ia dengar dan lihat, adalah perilaku konkrit dari orang-orang yang berada di sekelilingnya. Satu-satunya aturan dan batasan bagi anak adalah contoh yang dia lihat. Sehingga sangat sulit bagi anak untuk memahami aturan atau hukum yang bersifat tertulis atau hanya kata-kata yang tidak disertai dengan perilaku konkrit karena hal tersebut sangat abstrak baginya. Hal tersulit dalam pendidikan moral melalui wadah keluarga adalah bahwa pendidikan tersebut harus dimulai dari keluarga, yang benar-benar menjunjung tinggi dan mempraktekan nilai-nilai moral dalam kehidupan sehari-hari. Bila disepakati bahwa dari keluarga dapat membentuk pribadi yang bermoral, maka pertanyaan pertama yang muncul adalah, apa yang harus dimiliki oleh sebuah keluarga, bila benar-benar ingin membentuk pribadi yang bermoral? Pertanyaan ini diajukan, karena disadari betul bahwa kita tidak dapat menabur benih di atas batu. Hal pokok yang harus dimiliki oleh keluarga dalam membentuk moral adalah tauladan.

John Loke (Brennan 1999:30) mengatakan bahwa

Pada hakekatnya manusia ketika dilahirkan ke dunia, ia tidak ubahnya seperti sebuah kertas putih (tabula rasa) di mana tidak ada sedikitpun coretan atau tulisan di atasnya. Lingkunganlah yang akan menggoreskan ribuan tulisan dalam setiap lembarnya. Keluarga merupakan lingkungan pertama dan utama, bagi seorang anak menerima pelajaran pertamanya. Segala bentuk pondasi sebagai seorang manusia berasal dari rumah, demikian pula halnya dengan pendidikan moralnya.

Menurut Ahmad (2005:25), terdapat tiga faktor yang menjadi alasan mengapa keluarga menjadi tempat terbaik bagi pendidikan moral anak, yaitu: Pertama: ikatan darah; Secara umum, keterikatan darah membawa perasaan bahwa tidak ada yang lebih dipedulikan oleh seorang ayah atau ibu, selain anaknya, atau tidak ada yang lebih peduli kepada seorang anak, kecuali orang tuanya. Dalam hal ini, anak mendapatkan kebutuhan utamanya, yaitu cinta kasih, yang akan membentuk kepercayaan dalam dirinya bahwa kebaikan itu ada, mewujud, dan di alami. Sangat jelas di sini, bahwa kebaikan pertama kali diterima oleh anak-anak, bukan dalam bentuk konsep atau pengetahuan, tapi tindakan praktis atau dialami, Kedua, kekuasaan; Orang tua berkuasa penuh atas anaknya, baik secara fisik maupun psikologis, bahkan hidup dan mati seorang anak dapat dikatakan tergantung dari orang tuanya. Kekuasaan biasanya terwujud dalam bentuk pola pengasuhan (parenting style) yang diterapkan orang tua terhadap anaknya. Ketergantungan inilah, yang membuat orang tua berkuasa untuk mengucapkan kata-kata agar didengar, menunjukkan perilaku agar dicontoh (Hofflman, paris \& Hall 1994:55), Ketiga, harapan; Ada harapan pada diri setiap orang tua, bahwa anaknya dapat menjadi manusia yang baik bahkan jauh lebih baik dan lebih sempurna daripada orang tuanya tersebut. Hampir dapat dipastikan bahwa tidak ada orang tua yang ingin anaknya menjadi seorang koruptor sekalipun orang tuanya adalah 
seorang koruptor yang ulung. Harapan setiap orang tua kepada anaknya selalu menuju kearah yang baik dan positif. Hal ini mendorong orang tua mengarahkan anaknya menuju apa yang dia inginkan (Collins 2006:20).

Jalur pendidikan yang kedua adalah pendidikan melalui sekolah yang disebut jalur pendidikan formal, jalur pendidikan formal merupakan jalur utama pendidikan, karena pendidikan formal di sekolah ini yang benar - benar terstruktur, bertahap, bertingkat, dan berkelanjutan, yang tercantum dalam UU No. 20 tahun 2003 tentang Sistem Pendidikan Nasional (SISDIKNAS). Sedangkan jalur pendidikan yang ketiga kita sebut jalur pendidikan nonformal, yaitu jalur masyarakat. Ini meliputi segenap lapisan lingkungan kita (lingkungan tempat tinggal, tempat bekeria, tempat usaha maupun lingkungan penyampaian informasi melalui media), termasuk melalui lingkungan aparatur pemerintah (negara). Sementara itu, untuk pendidikan agama yang merupakan hal penting dalam penanaman dan pembangunan karakter, kita bisa gunakan ketiga jalur yang ada tadi, yakni informal, formal dan nonformal.

\section{PERMASALAHAN}

Berdasarkan uraian tersebut di atas, yang menjadi perumusan masalah dalam tulisan ini adalah apakah pendidikan karakter berdasarkan pengamalan nilai - nilai moral Pancasila dapat dijadikan dasar sebagai jati diri bangsa Indonesia?

\section{PEMBAHASAN}

PENDIDIKAN

KARAKTER

BERDASARKAN NILAI - NILAI

MORAL PANCASILA SEBAGAI JATI DIRI BANGSA INDONESIA

Tidak ragu lagi pendidikan karakter merupakan upaya yang harus melibatkan semua pihak baik rumah tangga dan keluarga sekolah dan lingkungan sekolah lebih luas masyarakat. Karena itu, langkah pertama yang harus dilakukan adalah menyambung kembali hubungan dan educational networks yang hampir terputus antara ketiga lingkungan pendidikan ini. Pembentukan dan pendidikan karakter tidak akan berhasil selama antara ketiga lingkungan pendidikan tidak ada kesinambungan dan harmonisasi. Dengan demikian, rumah tangga dan keluarga sebagai lingkungan pembentukan dan pendidikan karakter pertama, utama mestilah diberdayakan kembali. Sebagaimana disarankan Phillips, keluarga hendaklah kembali menjadi school of love, sekolah untuk kasih sayang (Phillips 2000:50).

Dan, sekali lagi, sekolah seperti sudah sering dikemukakan banyak orang sebaiknya tidak hanya menjadi tempat belajar, namun sekaligus juga tempat memperoleh pendidikan, termasuk pendidikan karakter. Sekolah, pada hakikatnya bukanlah sekadar tempat transfer of knowledge belaka. Seperti dikemukakan Fraenkel (1977: 1-2), sekolah tidaklah semata-mata tempat di mana guru menyampaikan pengetahuan melalui berbagai mata pelajaran. Sekolah juga adalah lembaga yang mengusahakan usaha dan proses pembelajaran yang berorientasi pada nilai (value-oriented enterpris). Lebih lanjut, Fraenkel mengutip John Childs 
yang menyatakan, bahwa organisasi sebuah sistem sekolah dalam dirinya sendiri merupakan sebuah usaha moral (moral entreprise), karena ia merupakan usaha sengaja masyarakat manusia untuk mengontrol pola perkembangannya.

Pembentukan dan pendidikan karakter melalui sekolah merupakan usaha mulia yang mendesak untuk dilakukan. Bahkan, kalau kita berbicara tentang masa depan, sekolah bertanggung jawab bukan hanya dalam mencetak peserta didik yang unggul dalam ilmu pengetahuan dan teknologi, tetapi juga dalam karakter dan kepribadian. Dan hal ini relevan secara kontekstual bukan hanya di negara-negara yang tengah mengalami krisis karakter seperti Indonesia, tetapi juga bagi negaranegara maju (cf. Fraenkel, 1977: Kirschenbaum \& Simon, 1974:65).

Usaha pembentukan dan pendidikan karakter melalui sekolah dapat dilakukan setidaknya melalui perdekatan, sebagai berikut:

Pertama, menerapkan pendekatan modelling atau dengan mensosialisasikan dan membiasakan lingkungan sekolah untuk menghidupkan dan menegakkan nilai-nilai akhlak dan moral yang benar melalui model atau teladan. Setiap guru dan tenaga kependidikan di lingkungan sekolah hendaklah mampu menjadi role mode yang hidup (living exemplary) bagi setiap pendidik. Mereka juga harus terbuka dan siap untuk mendiskusikan dengan peserta didik tentang berbagai nilai yang baik tersebut.

Kedua, menjelaskan atau mengklarifikasikan kepada serta didik secara terus-menerus tentang berbagai nilai yang baik dan yang buruk. Usaha ini bisa dibarengi pula dengan langkah-langkah; memberi penghargaan (prizing) dan menumbuh suburkan (cherising) nilai-nilai yang baik, dan sebaliknya mengecam dan mencegah (discouraging) berlakunya nilainilai yang buruk; menegaskan nilai-nilai yang baik dan buruk secara terbuka dan kontinu; memberikan kesempatan kepada peserta didik untuk memilih berbagai alternatif sikap dan tindakan berdasarkan nilai; melakukan pilihan secara bebas setelah menimbang dalam-dalam berbagai konsekuensi dari setiap pilihan dan tindakan; membiasakan bersikap dan bertindak atas niat dan prasangka baik dan tujuan-tujuan ideal; membiasakan bersikap dan bertindak dengan pola-pola yang baik yang diulangi secara terus-menerus dan konsisten.

Ketiga, menerapkan pendidikan berdasarkan karakter (character based education). Hal ini bisa dilakukan dengan menerapkan character based approach ke dalam setiap mata pelajaran yang ada di samping mata pelajaran khusus untuk pendidikan karakter, seperti pelajaran agama, sejarah, Pancasila, dan sebagainya, berinteraksi pada pembentukan karakter

Dalam konteks ini (UNESCO, 1998), deklarasi yang dirumuskan pada "World Conference on Higher Education" (Paris, 5-9 Oktober 1998) menyangkut misi dan fungsi pendidikan, dalam hal ini perguruan tinggi, antara lain, dinyatakan: bahwa perguruan tinggi juga memiliki misi dan fungsi untuk membantu melindungi dan memperkuat nilai-nilai sosial dengan melatih anak-anak muda dalam nilai-nilai yang mernbentuk dasar kewarganegaraan demokratis; dan dengan memberikan perspektif kritis dan tidak bias guna membantu dalam pembahasan tentang pilihan-pilihan strategis, dan penguatan perspektif humanistik. 
Di lihat dari segi ini, maka pendidikan termasuk di perguruan tinggi bertugas mengembangkan setidak-tidaknya lima bentuk kecerdasan. Pertama, kecerdasan intelektual; kedua, kecerdasan emosional; ketiga, kecerdasan praktikal; keempat, kecerdasan sosial; dan kelima, kecerdasan spiritual dan moral. Kelima bentuk kecerdasan ini harus dikembangkan secara simultan; dan jika berhasil dilaksanakan dengan baik, maka akan mampu menghasilkan mahasiswa dan lulusan yang bukan hanya cerdas secara intelektual, tetapi juga cerdas secara emosional, praktikal, sosial, dan spiritual-moral.

Dalam kerangka paradigma baru pendidikan nasional itu, kiranya baik pula di kutip rumusan tentang "nilai-nilai dasar pendidikan nasional" yang terdiri dari delapan butir. Pertama, keimanan dan ketakwaan, yakni bahwa pendidikan harus memberikan atmosfer religiusitas kepada peserta didik. Kedua, kemerdekaan, yakni kebebasan dalam pengembangan gagasan, pemikiran, dan kreativitas. Ketiga, kebangsaan, yakni komitmen kepada kesatuan kebangsaan dengan sekaligus menghormati pluralitas. Keempat, keseimbangan dalam perkembangan kepribadian dan kecerdasan anak. Kelima, pembudayaan, yakni memiliki ketahanan budaya dalam ekspansi budaya global. Keenam, kemandirian dalam pikiran dan tindakan, tidak bergantung pada orang lain. Ketujuh, kemanusiaan, yakni menghormati nilai-nilai kemanusiaan, akhlak, budi pekerti dan keadaban. Kedelapan, kekeluargaan, yakni ikatan yang erat antara komponen sekolah, keluarga, dan masyarakat. (Azyumardi Azra, 2006:184)

Dalam hubungannya dengan nilai-nilai yang terkandung di dalam Pancasila, pembukaan UUD 1945 dan dalam pribadi bangsa Indonesia, yang perlu diperhatikan ialah nilai-nilai yang telah disepakati oleh bangsa Indonesia sehingga mempunyai kekuatan yang mengikat, lebih tinggi dan nilai-nilai yang sedang hidup berkembang dalam masyarakat yang masih memerlukan kristalisasi. Meskipun di lihat dari segi hukum norma-norma hukum mempunyai kekuatan mengikat yang lebih tinggi dan sanksi yang lebih kuat (dapat memaksakan pelaksanaannya), dilihat dari segi kemanfaatan, norma hukum dan bukan norma hukum mempunyai pengaruh timbal-balik, saling mengisi.

Oleh sebab itu pengamalan Pancasila sebagai pandangan hidup bangsa berarti melaksanakan Pancasila dalam hidup sehari-hari. Pengamalan dalam hidup sehari-hari tidak boleh bertentangan dengan pengamalan dalam kehidupan kenegaraan dan hidup kemasyarakatan dalam negara. Jadi harus serasi dan harmonis. Karena corak dan ragam dalam kehidupan sehari-hari yang bersifat jamak (pluralistis), bermacam ragam maka sukar dibuat peraturan-peraturan secara terperinci dan menyeluruh, sebagaimana peraturan perundangan negara. Oleh sebab itu pengamalannya diserahkan kepada kesadaran dari masyarakat itu sendiri terhadap Pancasila asal tidak bertentangan dengan norma-norma yang berlaku (norma hukum, norma agama, norma kesusilaan, norma kesopanan dan adat kebiasaan yang ada).

Pengamalan Pancasila sebagai dasar negara disebut pengamalan Pancasila secara obyektif, sedangkan pengamalan Pancasila sebagai pandangan hidup bangsa disebut pengamalan secara subyektif. Pengamalan Pancasila secara subyektif meliputi bidang yang luas antara lain ekonomi, politik, sosial budaya, hankam, agama dan kepercayaan terhadap Tuhan 
Yang Maha Esa. Meliputi juga lingkungan hidup pribadi, hidup keluarga, hidup kemasyarakatan dan lain - lain. Kesemuanya harus dipertanggungjawabkan secara obyektif, secara filosofis, secara sosiologis dan secara moral dan etis sesuai dengan keadaan dan kapan dilaksanakan, ditentukan waktu dan tempat, baik sendiri maupun bersamasama.

Pengamalan secara subyektif inilah yang utama (primer). Bahkan yang menentukan: artinya pengamalan obyektif hanya dapat berlangsung dengan baik apabila terlebih dahulu pengamalan subyektif dapat baik. Untuk menuju terwujudnya pengamalan subyektif yang baik, maka secara bertahap sebaiknya di tempuh melalui pendidikan. Sebab melalui pendidikan inilah, kepada para subyek (manusia-manusianya) akan dapat diberikan pengertian dan pengetahuan yang tepat mengenal arti dan makna dari pada Pancasila. Dan hanya dengan pengetahuannya yang tepat atau yang baik, barulah dapat diharapkan tumbuhnya kesadaran, dan kemudian dari rasa kesadaran diharapkan adanya rasa ketaatan dan kemampuan untuk mengamalkan nilai-nilai Pancasila dalam kenyataan hidup sehari-hari.

Situasi ideal dalam pengamalan Pancasila yang seharusnya dapat kita capai adalah, bagaimana kita semua di dalam mengamalkan Pancasila itu tidak hanya sekedar didasarkan pada kewajiban hukum saja melainkan juga didasarkan pada kewajiban moral atau etis. Kewajiban moral atau etis di dalam mengamalkan Pancasila mengandung makna bahwa hati nurani kita sendirilah yang mewajibkan diri kita masing-masing untuk selalu berorientasi kepada nilai-nilai Pancasila itu, yaitu bertaqwa kepada Tuhan Yang Maha Esa menurut agama/kepercayaan kita masing-masing, memandang sesama ma-nusia sebagai makhluk yang sama harkat dan derajatnya, mendahulukan persatuan dan kesatuan masyarakat/ bangsa, segala sesuatu dimusyawarahkan demi tercapainya keadilan di mana masing-masing dapat memiliki apa yang memang menjadi haknya.

Oleh karena itu diperlukan teknik membangun karakter melalui pelatihan secara terus menerus sejak lahir sampai akhir hayat atau never ending process. Mengedepankan akhlak sebelum ilmu. Sistem pendidikan di Indonesia selama ini lebih mengedepankan pendidikan ilmu daripada akhlak karimah sehingga terciptalah manusia yang pandai tetapi tidak berkarakter. Orang yang baik belum dapat dikatakan berkarakter, sebelum kebaikannya dapat diaplikasikan dan dapat memberikan manfaat kepada orang lain dan dalam sekala lebih besar kepada Bangsa dan Negara. Karakter adalah suatu sifat yang dipadukan antara sifat nilai-nilai moral dari luar yang kita internalisasikan ke dalam diri kita dan potensi yang ada di dalam diri kita yang merupakan potensi pemberian Tuhan sebagai jati diri kita yang menjadi sifat dasar, dipadukan lalu dalam perjalanan hidup kita memilih sifatsifat yang akan dijadikan menjadi nilai hakiki. Contoh; kejujuran, tidak bisa kita terima langsung jadi begitu saja, harus diperjuangkan di dalam setiap tindakan kita, mampu tampil jujur, baru dapat dikatakan sebuah karakter.

Pembangunan karakter bangsa bertujuan membangun ketahanan pribadi dan ketahanan keluarga yang menjadi tumpuan bagai Ketahanan Nasional. Rapuhnya ketahanan Nasional dikarenakan oleh lemahnya ketahanan pribadi dan ketahanan keluarga. Kelemahannya selama ini dikarenakan 
Ketahanan Pribadi hanya mengejar kompetensi atau pengetahuan saja. Ketahanan pribadi tidak mempelajari pembangunan karakter. Karakter pribadi yang merupakan kunci, tidak disentuh dari semua lini. Yang menjadi permasalahan adalah tidak adanya pedoman yang jelas untuk membangun karakter. Karena tidak memahami karakter akhirnya yang dipelajari dalam kurikulum Diknas hanya pengetahuan dan keterampilan umum saja. Pembangunan karakter hanya diharapkan dari rumah saja. Tugas pokok ibu membangun karakter anak yang tidak sebagaimana mestinya menjadi awal kemerosotan bangsa.

Durkheim (dalam Kohlberg, 1995:75) menyatakan bahwa pendidikan dalam lingkungan keluarga merupakan suatu persiapan yang sangat menentukan bagi perkembangan moral anak, namun kegunaannya cukup terbatas terutama dalam hal semangat disiplin. Hal yang esensial bagi semangat disiplin yaitu rasa hormat terhadap peraturan, hampir tidak dapat berkembang dalam lingkungan keluarga. Salah satu hal yang mempengaruhinya adalah hubungan di antara anggota keluarga tidak dikendalikan oleh aturan umum yang tidak dapat diubah. Relasi antar anggota keluarga umumnya berada dalam suasana kebebasan. Suasana kebebasan tersebut menyebabkan minimnya rasa hormat terhadap peraturan. Di sisi lain, anak harus belajar menghormati peraturan, ia harus bertanggung jawab atas tugas-tugasnya.

Hal inilah yang kemudian menjadi tanggung jawab sekolah dalam mengembangkan tanggungjawab dan menghormati peraturan secara lebih dewasa. Terdapat suatu jarak yang besar antara keadaan moral yang dialami anak ketika ia meninggalkan keluarganya dan keadaan moral yang harus diusahakan. Diperlukan suatu perantara yang kondusif bagi perkembangan moral anak. Sekolah sebagai perantara yang merupakan suatu komunitas baru bagi anak yang diharapkan dapat membantu mengasah dan memupuk perkembangan moral anak dengan metode dan sistem pendidikan yang baik.

Beberapa hal penting diketahui antara lain: 1) seperti apakah pendidikan yang baik, 2) bagaimana fungsi dan metode yang terbaik agar perkembangan moral anak. dapat berkembang secara optimal? Menurut Ismail (2006:50) secara umum sekolah sebagai saranan pendidikan sekurangkurangnya memiliki 4 fungsi utama; pertama sebagai sarana transfer ilmu pengetahuan, kedua. konservasias dan pengembangan ilmu pengetahuan, ketiga, penguasaan life skill dan teknologi, keempat, sarana pembangunan karakter (character building). Keempat fungsi pendidikan di atas seharusnya berjalan sesuai dengan proporsi yang seimbang, sehingga menghasilkan suatu output yang benarbenar kompeten dalam bidang ilmu pengetahuan. Bukan saja mampu mengandalkan kemampuan pikir dan kognitif yang baik tetapi juga memiliki jiwa dan karakter yang luhur.

Pada kenyataannya, dari keempat fungsi pendidikan yang dikemukakan oleh Ismail (2006) umumnya hanya tiga fungsi yang dijalankan, yaitu sebagai transfer ilmu, konservasi dan pengembangan ilmu serta penguasaan life skill dan teknologi. Sedangkan fungsi yang keempat yaitu sarana pembangunan karakter, masih jauh dari aplikasi. Ketimpangan ini menyebabkan ketidakseimbangan output antara kemampuan kognitif dengan pembentukan karakter yang positif yang 
mengakibatkan munculnya pribadi-pribadi yang cacat secara nilai.

Hal ini terbukti dengan pelaku-pelaku korupsi yang berasal dari golongan cendekiawan dan terpelajar. Pada banyak kasus terutama kasus korupsi kelas kakap pelakunya adalah orang-orang yang terpelajar dan sangat ahli dalam bidangnya. Fenomena ini jelas menggambarkan bahwa fungsi pendidikan di Indonesia tidak sesuai dengan sistem yang diberlakukan. Hal ini didukung oleh pernyataan Ismail (2006), bahwa dari segi sistem, lembaga pendidikan di Indonesia telah gagal dalam menjalankan fungsinya sebagai kawah candradimuka bagi pembentukan karakter bangsa. Oleh sebab itu, salah satu "pekerjaan rumah" sistem dan lembaga pendidikan di Indonesia saat ini adalah mengembalikan pendidikan pada fungsinya sebagai pembentuk karakter bangsa yang tidak hanya bertugas sebagai sarana transfer ilmu pengetahuan, pengembangan keilmuan, penguasaan life skill dan teknologi, tetapi juga sebagai intemalisasi nilai-nilai luhur dan ideal bagi masyarakat. Nilai-nilai moral merupakan salah satu unsur dalam nilai-nilai luhur yang dimaksud.

Pendidikan anti-korupsi mulai memasuki ranah pendidikan formal, mulai pendidikan dasar hingga pendidikan tinggi seharusnya berkaca pada ketimpangan fungsi dan sistem pendidikan umum yang telah berjalan di Indonesia. Harapannya adalah agar output dari pendidikan antikorupsi tidak terjerumus pada lubang yang sama. Fungsi pembangun karakter harus mendapatkan porsi yang sesuai bahkan sedikit lebih diutamakan karena dalam fungsi ini, terdapat fungsi internalisasi nilai-nilai luhur dan nilai-nilai moral yang berperan sebagai penyeimbang antara kemampuan analisis dan kognitif serta psikomotorik. Jika fungsi internalisasi nilai-nilai moral ini tidak terasah, maka dapat dipastikan peserta didik pendidikan anti-korupsi hanya mampu memahami konsep anti-korupsi, bahaya korupsi, bahkan hukum yang berkaitan dengan korupsi sebatas pada tataran pengetahuan semata dan pendidikan anti-korupsi tidak akan menghasilkan output yang diharapkan yaitu mampu membentuk dan merubah perilaku peserta didik untuk mampu menampilkan diri sebagai individu pembawa perubahan (agent of change) yang anti-korupsi baik dalam segi perkataan maupun perilaku konkrit.

\section{PENDIDIKAN NILAI - NILAI MORAL BERKERJA MEMBENTUK PRIBADI ANTI-KORUPSI}

Sebuah pertanyaan penting, bagaimana pendidikan nilai-nilai moral bekerja membentuk pribadi anti-korupsi? inti dari pendidikan moral adalah pembentukan prinsip-prinsip keadilan. Pendidikan moral yang tepat, bersifat individual/personal. Semakin bersifat individual/personal pendidikan moral yang diberikan maka semakin besar kemungkinan terbentuknya prinsip-prinsip keadilan tersebut.

Kohlberg (1995:20) menyatakan bahwa prinsip yang paling inti bagi perkembangan pertimbangan moral individu adalah prinsip-prinsip keadilan. Keadilan sebagai penghargaan utama terhadap nilai dan persamaan derajat semua manusia serta terhadap timbal-balik dalam hubungan antar manusia, merupakan tolok ukur yang mendasardan universal. Menggunakan prinsip keadilan sebagai prinsip penata dalam pendidikan moral, memenuhi semua kriteria yang harus dipenuhi karena mampu menjamin kebebasan dalam berkeyakinan, menggunakan konsep moralitas yang dapat dibenarkan secara filosofis dan didasarkan atas fakta-fakta 
psikologis dari perkembangan manusia. Tujuan akhir dari pendidikan moral adalah terbentuknya prinsip-prinsip keadilan. Pendidikan moral mengenai anti-korupsi seharusnya memiliki tujuan akhir berupa terbentuknya prinsip-prinsip anti-korupsi. Prinsip di sini diartikan sebagai sebuah idealisme individual terhadap nilai-nilai anti-korupsi yang akan mempengaruhi domain kognitif, afektif, dan psikomotor dalam berperilaku sesuai dengan jalur yang sebenarnya dan seharusnya.

Domain kognitif, afektif dan psikomotor anti-korupsi yang tidak dilandasi dengan prinsip-prinsip anti-korupsi hanya akan menghasilkan pengetahuan. hukum atau aturan dalam diri individu semata. Hal yang perlu diperhatikan utuk dibedakan adalah istilah prinsip dan hukum/aturan. Prinsip tidak sama dengan hukum/aturan. Prinsip jika dibuat suatu contoh kalimat: "saya tidak akan korupsi...", "saya....tidak akan pernah mencuri uang rakyat", "saya tidak akan berzina" dan seterusnya. Sedangkan aturan jika dibuat suatu contoh kalimat: "jangan korupsi....", "jangan mencuri uang rakyat". "jangan berzina" dan seterusnya. Dari contoh kalimat di atas membuktikan bahwa prinsip yang lahir dari pendidikan moral yang tepat, bersifat individual/personal, sedangkan hukum/aturan diciptakan untuk dipatuhi bersama secara komunal.

Prinsip-prinsip antikorupsi yang diinternalisasi akan melahirkan karakter anti-korupsi yang akhirnya akan membentuk suatu kepribadian yang antikorupsi. Dalam tataran mikro, pendidikan anti-korupsi yang ideal seharusnya tidak hanya menyajikan materi-materi antikorupsi, hukum-hukum yang berkenaan dengan anti-korupsi yang menjurus kepada pengetahuan kognitif semata, tetapi sebaiknya dan seharusnya diimbangi dengan intemalisasi nilai-nilai moral yang akan membentuk prinsip-prinsip keadilan dalam tataran personal. Bahkan lebih jauh lagi, dalam tataran yang lebih makro, nilainilai moral yang membentuk prinsipprinsip keadilan tersebut selayaknya diterapkan pada semua bidang keilmuan (bukan saja pada mata kuliah anti-korupsi) sehingga ilmu pengetahuan tidak berhenti dan terbatas pada domain kognitif saja.

Bangsa Indonesia adalah bangsa yang berkarakter, karena memiliki ciri khusus yang membedakannya dengan bangsa lainnya. Keanekaragaman suku bangsa yang mendiami seluruh pelosok nusantara, janganlah dilihat secara terpisah-pisah tetapi saling berinteraksi, sesungguhnya mereka semua telah bersatu padu dalam sifat, watak, dan karakter yang saling mempengaruhi antar suku, karena telah terjadi keterpaduan, saling melengkapi antara sekumpulan nilai dan norma pada semua kelompok sosial yang ada, maka terbentuklah karakter bangsa Indonesia (Sulaiman, 2012:65)

Secara umum, Bangsa Indonesia memiliki Sembilan Pokok Karakter Bangsa, sebagai berikut:

1. Bangsa Indonesia adalah bangsa berintegritas.

Jiwa komunitas dari setiap suku bangsa dilengkapi oleh sifat suka bergaul, suka berdagang dan suka berkelana dan berhubungan dengan bangsa asing, membentuk bangsa Indonesia menjadi bangsa berjiwa integritas, menghargai persahabatan, memegang teguh janji dan komitmen.

2. Bangsa Indonesia adalah bangsa yang berani.

Jiwa berani bangsa Indonesia semula berasal dari masyarakat nelayan atau 
pelaut, dengan mengendarai perahu yang kecil berani menempuh samudra luas dan menempuh gelombang dan badai yang besar, tentu berbekal pengalaman, keahlian dan keterampilan serta rakyat Indonesia di kenal pelaut yang ulung. Jiwa bangsa Indonesia berani menghadapi berbagai kesulitan dan tantangan.

3. Bangsa Indonesia adalah bangsa yang tabah.

Jiwa yang tabah menghadapi penderitaan dan kesulitan terutama berasal dari petani, yang setiap subuh mereka berjalan naik gunung, turun gunung, lalu mencangkul dan menanam di sawahnya begitu pula dengan para nelayan mereka mempunyai hambatan dalam kehidupannya. Jiwa bangsa Indonesia adalah jiwa yang tabah menghadapi berbagai kesulitan dan penderitaan serta sabar menjalani hidup apa adanya.

4. Bangsa Indonesia adalah bangsa yang jujur.

Semua suku bangsa di Indonesia asal mulanya mereka adalah orang-orang yang lugu, jujur, tidak pernah berbohong, tidak licik, tidak pernah menipu, tidak pernah berlaku curang dalam hal apapun. Mereka tidak culas dan tidak pernah menyembunyikan sesuatu, mereka berkata apa adanya. Adanya suku bangsa yang tertutup terhadap pengaruh luar, semata-mata ingin menjaga keluguan dan kejujuran semua anggota sukunya.

5. Bangsa Indonesia adalah bangsa yang setia.

Kehidupan dalam komunitas suku manapun di Indonesia menjunjung tinggi kesetiaan, setia kawan mendorong terwujudnya gotong royong dalam penyelesaian segala kesulitan dan pekerjaan dikomunitasnya, seperti: gugur gunung, pindah rumah, arisan, irigasi pertanian/subak dan lain-lain. Jiwa bangsa Indonesia adalah jiwa yang setia yang selanjutnya mewujudkan kebersamaan, gotong royong, kepedulian dan solidaritas serta kekeluargaan.

6. Bangsa Indonesia adalah bangsa yang bermoral.

Masyarakat Indonesia adalah masyarakat religius, yang agamis, maka moral bangsa Indonesia bersumber dari agama yang dianut. Moral masyarakat Indonesia bersumber dari cinta akan kebenaran, terutama kebenaran dalam bidang agama. Moral bangsa Indonesia sudah melekat dan mendarahdaging secara kodrati yang sudah terbentuk secara konsisten dalam sikap dan perilaku seharihari.

7. Bangsa Indonesia adalah bangsa yang beretika.

Setiap anggota suku apapun di Indonesia dituntut untuk bertanggung jawab, dan pelaksanaan tanggung jawab diharuskan sesuai dengan etika yang berlaku Kebiasaan beretika sudah mendarah daging pada masyarakat Indonesia.

8. Bangsa Indonesia adalah bangsa yang kreatif dan berbudaya tinggi.

Masyarakat Indonesia adalah masyarakat yang bijaksana, sebab dengan kebijaksanaan akan mempererat persahabatan, 
memperlancar komunikasi, meningkatkan hubungan personal, sebagai bukti dari masyarakat yang berbudaya tinggi. Disamping menjunjung tinggi nilai-nilai kemanusiaan dalam cipta, rasa dan karsa, maka jiwa bangsa Indonesia adalah jiwa kreatif dan berbudaya tinggi.

9. Bangsa Indonesia adalah Bangsa yang Cinta Damai.

Setiap suku bangsa di seluruh pelosok nusantara selalu berusaha menjaga kerukunan dan kedamaian intern dan antar suku, semua lambang-lambang kesukuan adalah untuk melanggengkan persahabatan, kerukunan dan perdamaian. Cinta damai menuntut bangsa yang merdeka dan berdaulat, sebab bagaimana mungkin turut serta menciptakan perdamaian kalau tidak merdeka dan berdaulat?

\section{PENUTUP}

Pentingnya pendidikan karakter, setelah terwujud menjadi satu ruang yang disebut karakter, kemudian menjadi daya dorong dari dalam dan keluar, yang akan menuntun perilaku kita yang selalu mengarah kepada kebajikan dan kebaikan, menjadi orang baik yang terampil terpuji terus menerus, dimana orang yang tidak membangun karakternya tidak akan mempunyai daya dorong sehingga mendapatkan kesulitan dalam menemukan jatidirinya. Oleh karena itu konsep dasar pentingnya dimana setelah terwujud menjadi satu yang disebut karakter adalah membentuk karakter yang kokoh, kuat dan mulia sejak dini. Karakter yang harus dibangun adalah karakter yang diwarnai semangat esensi dan nilai-nilai Pancasila, ditaburi sejak kecil sikap dan prilaku pancasila yang telah berkembang di bumi pertiwi menjadi kekhasan Indonesia. Orang lain tidak memiliki Pancasila akan tetapi melakukan nilai-nilai Pancasila yang telah dirumuskan para Founding Father. Faktor utama dalam melaksanakan pendidikan karakter bangsa adalah adanya rasa ketulusan dan kesungguhan. Di samping itu perlu ada rasa keadilan untuk berbuat sesuatu atau bertekat memberi sekecil apapun untuk negara dan bangsa yang sudah sangat mengharapkan adanya suatu perubahan yang positif menuju kepada, kemajuan peradaban manusia diabad melinium. Dimana akselerasi seluruh kegiatan pengembangan Karakter Bangsa akan lebih terlihat dan akan menjadi lebih mantap, jika didukung keteladan dari para orang tua, pendidik, para tokoh, para pejabat dan para pemuka masyarakat. Oleh karena itu inti pelajaran Karakter Bangsa sebagai materi tambahan pada berbagai jenis pendidikan dan pelatihan, adalah berupa penekanan pada penanaman semangat kebersamaan dan pengabdian yang diaktualisasikan secara kondusif dan adaptif dalam kehidupan bermasyarakat, berbangsa dan bernegara dalam kegiatan kurikuler dan ekstra kurikuler.

\section{DAFTAR PUSTAKA}

\section{BUKU}

Ahmad. J. The Young Sufi, Jejak Cinta Sang Sufi Muda, Tinta, Yogyakarta. 2005

Azyumardi, Azar, Paradigma Bru Pendidikan Nasional, Kompas, Jakarta 2002

Brennan, J. F. Hystory and systems of psychology,six edition.Prentice Hall. New Jersey. 1999 
Collins, E.M. Konsep keluarga modern berdasarkan nilai - nilai moral tradisional., Titan Ilmu. Jakarta. 2006

Durkheim. E. Moral education : Astudy in The Theory and Aplication in the Sociology of education. Free Press New York, 1961

Darmodiharjo, S. Darji, dkk. SANTIAJI Pancasila Suatu Norma. Usaha Nasiona, Surabaya, 1991.

Fraenkel, Jack R., 1977, How to Teach about Values: An Analytical Approch, Englweood, NJ: Prentice Hall

Hoffman. L,Paris, S, Hall, E. Developmental psychology today, sixth editio. McGraw Hill. New York 1994

Ismail , dkk Pendidikan antikoropsi di perguruan tinggi,Center for the Studi of Religion and Culture (CSRC). Pusat Kajian Agama dan Budaya Universitas Islam Negeri (UIN). Jakarta 2006.

Kohlberg. L. Tahap-tahap perkembangan moral. Kanisius. Yogyakarta 1995.

Krischenbaum, Horward \& Sydney B. Simon, 1974 "Values and Futures Movement in Education", dalam Alvin Toffler (ed.), Learning for Tomorrow: The Role of the Future in Education, New York: Random House.

Phillips, C. Thomas, 2000, "Family as the School of Love" makalah pada National Conference on Character Buiding, Jakarta, 25 - 26 November, 2000.

UNESCO, 1998, Higher Education in the Twenty-First Century: Vision and Action, Paris: UNESCO

\section{PERUNDANG - UNDANGAN}

\section{UUD NRI Tahun 1945}

UU No. 20 Tahun 2003 tentang SISDIKNAS

UU No. 17 Tahun 2007 tentang Rencana Pembangunan Jangka Panjang Nasional $2005-2025$

\section{JURNAL}

Sulaiman, Jurnal SATRIA, Januari Maret 2013 Vol. 8 No.1, Konsep Dasar Pendidikan Karakter, KEMENHAN 